\title{
Characterization and overexpression of a novel keratinase from Bacillus polyfermenticus B4 in recombinant Bacillus subtilis
}

\author{
Yu-Ze Dong ${ }^{1}$, Wen-Shous Chang ${ }^{1,2}$ and Po Ting Chen ${ }^{\text {* }}$
}

\begin{abstract}
Background: Keratins, insoluble proteins with a robust structure, are a major component of epidermal tissue and appendages such as hair, feathers, nails, and walls. Keratinous waste mainly emanates from poultry and leather industries, thereby severely contaminating the environment. Keratinase can lyse proteins with robust cross-linked structures, such as keratin, and can hence be used in animal feed, fertilizer, detergent, leather, pharmaceutical, and cosmetic industries. Bacillus polyfermenticus B4, isolated from feather compost, secretes keratinase to metabolize feathers. Hence, this study aimed to investigate the enzymatic characteristics and recombinant production of keratinase from B. polyfermenticus B4.
\end{abstract}

Methods: A novel keratinase KerP was isolated from B. polyfermenticus B4 and overexpressed in B. subtilis PT5, via the T7 promoter.

Results: The highest keratinolytic activity of recombinant KerP was observed at $\mathrm{pH} 9.0$ and $60^{\circ} \mathrm{C}$. Enzyme activity was enhanced with $\mathrm{Fe}^{2+}, \mathrm{Mn}^{2+}$, and SDS, and inhibited by $\mathrm{Zn}^{2+}, \mathrm{Ni}^{2+}, \mathrm{EDTA}$, PMSF, and $\beta$-mercaptoethanol. KerP production was the highest at $473 \pm 20 \mathrm{U} / \mathrm{mL}$ with B. subtilis aprE signal peptide using LB broth.Conclusions: The novel keratinase KerP has potential industrial applications, particularly in the treatment of keratinous waste.

Keywords: Keratinase, Bacillus polyfermenticus, Keratinous waste, Characterization, Overexpression, Bacillus subtilis

\section{Background}

Keratin is an essential protein constituent of the animal epidermis and associated integuments such as feathers, hair, nails, scales, horns, and hooves. It is an insoluble protein and can be classified into two types, based on the content of disulfide bonds: soft and hard (Coulombe and Omary 2002). Soft keratin has low disulfide bond content and a soft and flexible texture, and is present in skin and healing tissue, whereas hard keratin has high disulfide bond content and a hard and less flexible texture, and is present in feathers, nails, and horns (Coulombe and Omary 2002). Keratins in the hair or wool primarily contain $\alpha$-helices, whereas those in feathers or nails primarily contain $\beta$-sheets (Onifade et al. 1998; Schrooyen et al.

\footnotetext{
*Correspondence: wind1975@gmail.com; ptchen@stust.edu.tw ${ }^{1}$ Department of Biotechnology, Southern Taiwan University of Science and Technology, Tainan 710, Taiwan

Full list of author information is available at the end of the article
}

2001; Wang and Parsons 1997). Cross-linking in keratin fibers occurs through disulfide bonds, hydrogen bonds, and hydrophobic interactions. General proteases such as trypsin and pepsin cannot degrade keratin (Gupta and Ramnani 2006; Kreplak et al. 2004; Olajuyigbe and Falade 2014).

Currently, keratinous wastes from poultry, fur, leather, and slaughter industries are gradually causing serious environmental problems (Korniłłowicz-Kowalska and Bohacz 2011; Onifade et al. 1998). Many attempts have been made to convert keratinous waste to smaller debris or protein hydrolysates through physical and chemical treatments (Gupta et al. 2013), which can then be used as nutrient additives in animal feed, agriculture, and cosmetic industries (Bhange et al. 2016). However, the conventional treatment methods could deteriorate the quality and stability of the hydrolyzed products, adding 
to environmental concerns such as strong acidification or alkalinization of water through the generated waste.

Keratinases are proteases that can particularly lyse recalcitrant proteins such as keratin (Onifade et al. 1998). Keratinases have been reported in many microorganisms such as bacteria, actinomycetes, and fungi (Bhange et al. 2016). Moreover, KerA, isolated from Bacillus licheniformis PWD-1, is the most well-characterized keratinase (Lin et al. 1995; Onifade et al. 1998). Keratinases bind to and cleave keratins at their hydrophobic sites. Based on their catalytic mechanism, most keratinases are either metalloproteases or serine-metalloproteases (Brandelli 2008; Bressollier et al. 1999).

Microorganisms isolated from keratin-rich environments such as poultry feather wastes, slaughterhouse wastes, and leather wastes, have high keratinolytic activity (Brandelli et al. 2010; Fakhfakh-Zouari et al. 2010; Khardenavis et al. 2009). Most of the keratinases from these strains are extracellular enzymes, with only a minute fraction being intracellular or associated with the cell wall. Because of their unique characteristics, keratinases have potential applications in industrial fields such as stock farming, poultry feather treatment, leather depilation, laundry detergents, and cosmetics. However, large-scale production of keratinase is essential for its application at the industrial level.

Previous studies have used various bacterial expression systems for keratinase production (Lin et al. 1997; Liu et al. 2014; Radha and Gunasekaran 2008). Bacillus subtilis can efficiently secrete native or heterologous proteins into the culture broth, which renders it an attractive strain for enzyme production at an industrial level. Moreover, B. subtilis is a generally recognized as safe (GRAS) bacterium, with promising application in protein requirement in food and in the clinical setting (de Boer Sietske and Diderichsen 1991; Harwood 1992; Pohl and Harwood 2010; Schallmey et al. 2004; Westers et al. 2004). Signal peptides play a very important role in protein secretion in B. subtilis (Brockmeier et al. 2006; Tjalsma et al. 2004); a suitable signal peptide could significantly enhance target protein secretion (Brockmeier et al. 2006; Li et al. 2004).

In this study, a keratinolytic bacterium Bacillus polyfermenticus B4 was isolated from soil feather composts in a chicken farm in Tainan and a novel keratinase KerP was isolated and cloned into B. subtilis PT5 for heterologous production. Furthermore, the biochemical characteristics and catalytic mechanism of KerP were investigated. Moreover, enzyme production in B. subtilis was evaluated by fusing the mature KerP polypeptide with different signal peptides.

\section{Methods}

\section{Isolation and screening of keratinolytic microorganisms from feather composts}

To isolate keratinolytic microorganisms, soil samples from feather composts were extracted from six areas (sample A to F) of a poultry farm in Tainan, Taiwan. Each 5 -g sample was suspended in $100 \mathrm{~mL}$ feather defined medium (defined medium containing $10 \mathrm{~g}$ of feathers) in a $500-\mathrm{mL}$ shake flask and incubated at $37{ }^{\circ} \mathrm{C}$ at $150 \mathrm{rpm}$. After 2 days of incubation, the feathers were disrupted in the culture medium containing sample B, and after 12 days of culturing, the feathers were decomposed to small debris, except for some broken rachis. Thereafter, $0.1 \mathrm{~mL}$ of diluted culture broth $\left(10^{-6}\right)$ containing sample B was spread on a plate containing defined medium and $1 \%$ skimmed milk. The halo-forming colonies thus formed were considered potential candidates for keratinase production, and inoculated into feather defined medium at $37^{\circ} \mathrm{C}$ at $150 \mathrm{rpm}$. Furthermore, $16 \mathrm{~S}$ rDNA sequencing was performed with primers $27 \mathrm{~F}$ and 1497R (Kim et al. 2000) to identify the microorganisms.

\section{Bacterial strains and culture conditions}

The bacterial strains used in this study are listed in Table 1. Gene cloning was performed in E. coli DH5 $\alpha$ and B. subtilis strain PT5 containing the T7 RNA polymerase for gene expression driven by the T7 promoter (Chen et al. 2010). For DNA manipulation, $E$. coli were grown in $10 \mathrm{~mL}$ of Luria-Bertani (LB) medium in a $125-\mathrm{mL}$ shake flask, and cell densities were determined through the optical density at $600 \mathrm{~nm}\left(\mathrm{OD}_{600}\right)$. For keratinase production, recombinant $B$. subtilis strains were cultured overnight at $37{ }^{\circ} \mathrm{C}$ and inoculated into a $250-\mathrm{mL}$ shake flask containing fresh LB medium $(30 \mathrm{~mL})$ with cell density of $\mathrm{OD}_{600}=0.1$, and then incubated in an orbital shaker at $200 \mathrm{rpm}$ and $37{ }^{\circ} \mathrm{C}$ for $24 \mathrm{~h}$. For the selection of E. coli harboring plasmids or $B$. subtilis integrants, the medium was supplanted with antibiotics ampicillin $(50 \mu \mathrm{g} / \mathrm{L}$ for $E$. coli) and erythromycin (10 $\mu \mathrm{g} / \mathrm{L}$ for B. subtilis).

\section{Construction of expression vectors for keratinase secretion} The vectors and primers used in this study are listed in Tables 1 and 2, respectively. The full-length keratinase gene kerP was amplified from B. polyfermenticus B4 through polymerase chain reaction (PCR) with primers $\mathrm{KP} 01$ and KP02. The PCR product of $\operatorname{kerP}(0.802 \mathrm{~kb})$ was digested with $\mathrm{NruI} / \mathrm{BamHI}$ and ligated with the integration vector $\mathrm{pDMT}$ to generate $\mathrm{pDMT}-\mathrm{KerP}$.

The PCR product of DMT-mKerP0102 $(5.033 \mathrm{~kb})$ was amplified from vector pDMT-KerP designed to eliminate the $\operatorname{ker} P$ signal peptide sequence, which was amplified 
Table 1 Strains and plasmids used in this study

\begin{tabular}{|c|c|c|}
\hline & Relevant characteristics & Source \\
\hline \multicolumn{3}{|l|}{ Strain } \\
\hline \multicolumn{3}{|l|}{ E. coli } \\
\hline $\mathrm{DH} 5 \mathrm{a}$ & deoR endA1 gyrA96 hsdR17 supE44 thi1 recA1 lacZM15 & Lab. collection \\
\hline \multicolumn{3}{|l|}{ B. subtilis } \\
\hline PT5 & DB428, $\Delta$ wpr::T7gene 1 & \\
\hline PT5(DMT-KerP) & $\mathrm{PT} 5, \Delta m p r:: \mathrm{P}_{\mathrm{T}} /$ kerP-erm & This study \\
\hline PT5(DMT1-mKerP) & $\mathrm{PT} 5, \Delta m p r:: \mathrm{P}_{\mathrm{T}} /$ aprE SP-mkerp-erm & This study \\
\hline PT5(DMT7-mKerP) & PT5, $\Delta m p r:: \mathrm{P}_{\mathrm{T} 7} / x y n D$ SP-mkerp-erm & This study \\
\hline PT5(DMT8-mKerP) & $\mathrm{PT} 5, \Delta m p r:: \mathrm{P}_{\mathrm{T}} /$ bglS SP-mkerp-erm & This study \\
\hline PT5(DMT12-mKerP) & PT5, $\Delta m p r:: \mathrm{P}_{\mathrm{T}} / m p r$ SP-mkerp-erm & This study \\
\hline PT5(DMT16-mKerP) & PT5, $\Delta m p r:: \mathrm{P}_{\mathrm{T} 7} / x y n A$ SP-mkerp-erm & This study \\
\hline PT5(DMT21-mKerP) & PT5, $\Delta m p r:: \mathrm{P}_{\mathrm{T}} / a b n A$ SP-mkerp-erm & This study \\
\hline \multicolumn{3}{|l|}{ Plasmid } \\
\hline $\mathrm{pDMT}$ & Integration vector contains by $\mathrm{P}_{\mathrm{T} 7}$ and $m p r^{\prime}$ & \\
\hline pDMT-KerP & pDMT with full-length kerP gene & This study \\
\hline pDMT1-mKerP & aprE SP instead of kerP SP in pDMT-KerP & This study \\
\hline pDMT7-mKerP & xynD SP instead of kerP SP in pDMT-KerP & This study \\
\hline pDMT8-mKerP & bg/S SP instead of kerP SP in pDMT-KerP & This study \\
\hline pDMT12-mKerP & mpr SP instead of kerP SP in pDMT-KerP & This study \\
\hline pDMT16-mKerP & xynA SP instead of kerP SP in pDMT-KerP & This study \\
\hline pDMT21-mKerP & $a b n A$ SP instead of kerP SP in pDMT-KerP & This study \\
\hline
\end{tabular}

erm, selection marker of erythromycin resistant; kerp, keratinase KerP full-length gene; mkerP, keratinase KerP mature sequence; $\mathrm{P}_{\mathrm{T} 7}, \mathrm{T7}$ promoter; $\mathrm{SP}$, signal peptide

by PCR with primers DMKP01 and 02 and plasmid pDMT-KerP as a template. Six signal sequences were amplified from the B. subtilis chromosome, using specific primer pairs. The PCR products of signal sequences were digested with $\mathrm{XhoI} / \mathrm{BamHI}$ and cloned into the PCR product DMT-mKerP0102 to generate the six integration vectors (Table 1 ).

Polymerase chain reaction was carried out using Q5 DNA polymerase (New England BioLabs) per the following protocol: pre-denaturation at $98{ }^{\circ} \mathrm{C}$ for $30 \mathrm{~s}, 25-30$ cycles of DNA amplification during amplification $98^{\circ} \mathrm{C}$ for $10 \mathrm{~s}$, annealing at $60{ }^{\circ} \mathrm{C}$ for $10 \mathrm{~s}$, elongation at $2 \mathrm{~kb} /$ min at $72{ }^{\circ} \mathrm{C}$; and a final extension step at $72{ }^{\circ} \mathrm{C}$ for $5 \mathrm{~min}$. The generated vectors were integrated into $B$. subtilis PT5 chromosome through double homologous recombination to generate KerP-producing strains.

\section{Analytical methods}

The keratinolytic activity assay protocol developed previously (Vermelho et al. 2010) was performed in this study, with minor modifications. The $0.1-\mathrm{mL}$ cell-free culture broth was added to a $0.4-\mathrm{mL}$ reaction mixture containing $0.05 \mathrm{M}$ Glycine- $\mathrm{NaOH}$ buffer ( $\mathrm{pH} 9.0$ ) and 10-mg feather powder (purchased from an agricultural materials store in Tainan, Taiwan). The reaction was carried out at $60^{\circ} \mathrm{C}$ for $1 \mathrm{~h}$ and terminated by adding 20\% trichloroacetic acid $(0.5 \mathrm{~mL})$. After centrifugation for $10 \mathrm{~min}$ at $4{ }^{\circ} \mathrm{C}$, $14,000 \mathrm{rpm}$, the optical density of the supernatant was determined at $280 \mathrm{~nm}$. One unit of keratinolytic activity (one unit) was defined as the amount of enzyme required to increase the $A_{280}$ by 0.01 .

The cell-free culture broth was harvested through centrifugation for $10 \mathrm{~min}$ at $4{ }^{\circ} \mathrm{C}, 14,000 \mathrm{rpm}$ for evaluating keratinase activity or production via SDS-PAGE on a $10 \%$ $(\mathrm{w} / \mathrm{v})$ polyacrylamide gel, as described previously (Chao et al. 2002).

\section{Temperature and $\mathrm{pH}$ dependence}

The optimal $\mathrm{pH}$ and temperature for KerP activity were determined using buffers of $\mathrm{pH} 5-12$ at $30-90{ }^{\circ} \mathrm{C}$. Different buffers were selected to cover a range of $\mathrm{pH}$ value by using Mcilvaine ( $\mathrm{pH}$ 5-6), Tris- $\mathrm{HCl}(\mathrm{pH} 7-8)$, and Glycine- $\mathrm{NaOH}$ (pH 9-12) buffers. Enzyme activity was analyzed as described above. To estimate the $\mathrm{pH}$ stability of KerP, the enzyme was incubated for different durations at $4{ }^{\circ} \mathrm{C}$. The thermal stability was determined by measuring the residual activity of the enzyme solution incubated at $30-90{ }^{\circ} \mathrm{C}$ for $10-60 \mathrm{~min}$.

\section{Batch fermentation}

A 5-L fermenter was used for batch fermentation of recombinant $B$. subtilis. After overnight fermentation, the 
Table 2 Primers used in this study

\begin{tabular}{|c|c|c|}
\hline & Relevant characteristics & Source \\
\hline \multicolumn{3}{|l|}{ Primer } \\
\hline $27 \mathrm{~F}$ & AGAGTTTGATCCTGGCTCAG & \\
\hline $1492 R$ & AAGTCGTAACAAGGTAACC & \\
\hline BP01 & GTGAGAGGCAAAAAGGTATG & \\
\hline BP02 & TTACTGAGCTGCCGCCTG & \\
\hline KP01 & ATCGTATCGCGAGTGAGAGGCAAAAAGGTATG (Nrul) & \\
\hline KP02 & CTATGAGGATCCTTACTGAGCTGCCGCCTG (BamHI) & \\
\hline DMKP01 & $\begin{array}{l}\text { TGACTATCGCGATTACCCTCTCCTTTTAAAAAATC } \\
(\text { Nrul) }\end{array}$ & \\
\hline DMKP02 & $\begin{array}{l}\text { TATGCTCTCGAGGGCAGGGAAATCAAACGGGGA } \\
(\text { Xhol) }\end{array}$ & \\
\hline aprE01 & $\begin{array}{l}\text { AGAGGGTCGCGAGTGAGAAGCAAAAAATTGTGG } \\
\text { (Nrul) }\end{array}$ & aprESP \\
\hline aprE02 & $\begin{array}{l}\text { GATCGACTCGAGGCAGCCTGCGCAGACATGTTG } \\
(\text { Xhol) }\end{array}$ & aprESP \\
\hline xynD01 & ATGCATTCGCGAATGAGGAAAAAGTGTAGCGT (Nrul) & xynD SP \\
\hline xynD02 & $\begin{array}{l}\text { TAGCTACTCGAGGCAGCATACGCAGACTTCCCAG } \\
(\text { Xhol) }\end{array}$ & xynD SP \\
\hline bglS01 & $\begin{array}{l}\text { ATGCATTCGCGAATGCCTTATCTGAAACGAGTG } \\
(\text { Nrul) }\end{array}$ & $b g / S$ SP \\
\hline bglSO2 & $\begin{array}{l}\text { TAGCTACTCGAGGCAGCTGAGGCAGTAGCAGTGA } \\
\text { (Xhol) }\end{array}$ & $b g / S$ SP \\
\hline mpr01 & $\begin{array}{l}\text { GGAAGTTCGCGAATGAAATTAGTTCCAAGATTCAG } \\
\text { (Nrul) }\end{array}$ & mpr SP \\
\hline mpr02 & $\begin{array}{l}\text { TAGCTACTCGAGGCCGCTTTTGCCGGTACGCCA } \\
\text { (Xhol) }\end{array}$ & mprSP \\
\hline xynA01 & $\begin{array}{l}\text { ATGCATTCGCGAATGTTTAAGTTTAAAAAGAATTTC } \\
\text { (Nrul) }\end{array}$ & xynA SP \\
\hline xynA02 & $\begin{array}{l}\text { TAGCTACTCGAGGCTGCAGAGGCGGTTGCCGAA } \\
(\text { Xhol) }\end{array}$ & xynA SP \\
\hline abnA01 & $\begin{array}{l}\text { GATGACTCGCGAATGAAAAAGAAAAAAACATGG } \\
(\text { Nrul) }\end{array}$ & $a b n A S P$ \\
\hline $\mathrm{abnA02}$ & TAGCTACTCGAGGCTGCCTCTGCGGGAGCAG (Xhol) & $a b n A S P$ \\
\hline
\end{tabular}

cell culture was inoculated into three $500-\mathrm{mL}$ shake flasks containing $200 \mathrm{~mL}$ fresh $\mathrm{LB}$ medium, with the initial cell density adjusted to $0.1\left(\mathrm{OD}_{600}\right)$. After $2 \mathrm{~h}$ of culturing, cultures from the three shake flasks were transferred into the fermenter. The final volume in the fermenter was adjusted to $3 \mathrm{~L}$ and the initial cell density was adjusted at $0.1\left(\mathrm{OD}_{600}\right)$. The working condition was set at $37^{\circ} \mathrm{C}$; initial $\mathrm{pH}, 7.0$; air flow, $1.5 \mathrm{vvm}$; and dissolved oxygen concentration (maintained through agitation), $20 \%$.

\section{Results and discussion}

\section{Isolation and screening of keratinolytic microorganisms} from feather composts

After 12 days of culturing in the feather meal medium, complete decomposition of feathers was observed only in flask B4. The results indicated that only the B4 strain could produce keratinase, while the other strains produced general proteases. Furthermore, $16 \mathrm{~S}$ rDNA sequencing (Kim et al. 2000) performed using strain B4, followed by sequence analysis by National Center for Biotechnology Information (NCBI) indicated that B4 strain showed $99.8 \%$ sequence similarity to B. polyfermenticus. Hence, the B4 strain was identified as B. polyfermenticus B4.

\section{Keratinase isolation from B. polyfermenticus B4 and production of recombinant keratinase}

The protein sequence of the commercially available keratinase KerA from B. licheniformis PWD-1 (Lin et al. 1995) was compared with that of B. polyfermenticus through a protein BLAST (https://blast.ncbi. nlm.nih.gov/Blast.cgi?PROGRAM=blastp\&PAGE TYPE=BlastSearch\&LINK_LOC=blasthome). KerA showed $65 \%$ similarity to alkaline protease precursor (GeneBank: ADP23919.1), using the protein database of $B$. polyfermenticus. This suggested that the alkaline protease precursor of $B$. polyfermenticus maybe attributed to keratinase and also existed in B. polyfermenticus B4. Two primers, $\mathrm{BP} 01$ and $\mathrm{BP} 02$, were designed for $B$. polyfermenticus SCN11 alkaline protease precursor (GeneBank: HQ436407.1). The single DNA fragment BP0102 was amplified through PCR with primers BP01-BP02 and $B$. polyfermenticus $\mathrm{B} 4$ chromosome as a template. The PCR product BP0102 was cloned into the plasmid pBluescript II SK(-) digested with EcoRV to generate pBlue-BP0102, which was then subjected to DNA sequencing (Tri-I Biotech, Inc., New Taipei City) with T7 and T3 primers. The DNA fragment was translated to the corresponding polypeptide in silico and a BLASTX was performed to compare the translated sequence with alkaline protease precursor protein. The result was showed in Additional file 1: Figure S1 revealed a $99 \%$ similarity with alkaline protease precursor (GeneBank: ADP23919.1). Therefore, this gene fragment was putatively referred to as KerP.

The KerP gene was amplified through PCR with primers KP01 and KP02 and then cloned into the integrant plasmid pDMT to generate pDMT-KerP, using NruI and BamHI. The plasmid pDMT-KerP was integrated into the B. subtilis PT5 chromosome, resulting in the new KerP-expressing strain PT5(DMT-KerP). This strain formed a clear halo in the LB plate containing skim milk. Moreover, this recombinant strain could digest the feathers completely in feather defined medium after 7 days of incubation. This proved that the $\operatorname{ker} P$ gene encodes a keratinase.

\section{Effect of $\mathrm{pH}$ and temperature on KerP activity}

With feather powder as the substrate, the highest KerP activity was observed at pH 9.0, (Fig. 1a) and the enzyme retained complete activity at $\mathrm{pH} 7-8$ after $48 \mathrm{~h}$ of storage 

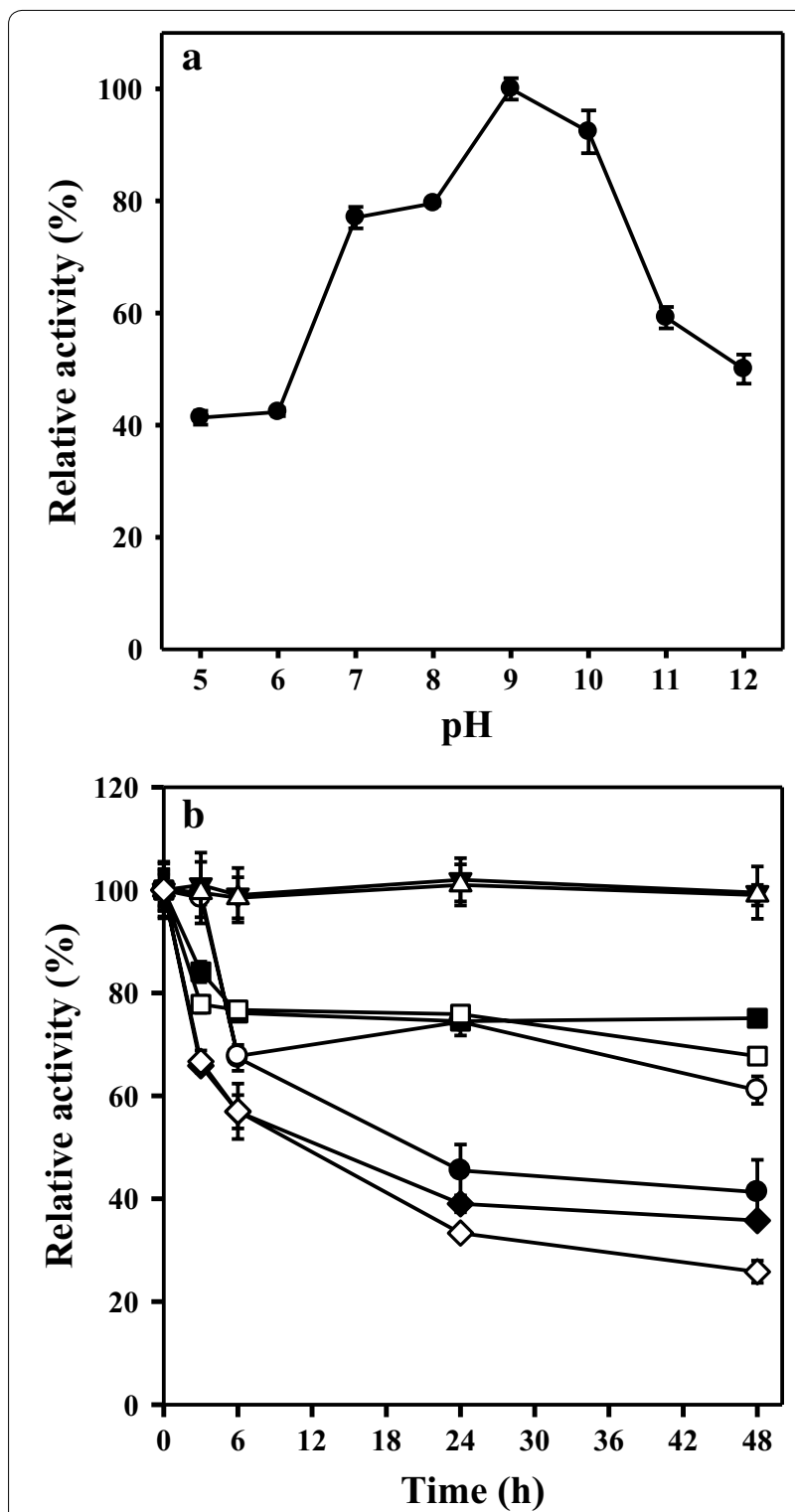

Fig. 1 a Effect of pH on KerP activity. $\mathbf{b}$ pH stability of KerP. Enzyme activity was preserved at various $\mathrm{pH}$ levels between 0 and $48 \mathrm{~h}$ before assaying enzyme activity. pH 5.0 (filled circle), pH 6.0 (open circle), pH 7.0 (filled inverted triangle), pH 8.0 (open triangle), pH 9.0 (filled square), $\mathrm{pH} 10.0$ (open square), $\mathrm{pH} 11.0$ (filled diamond), $\mathrm{pH}$ 12.0 (open diamond). The enzyme activity was assayed with feather powders as the substrate at $60^{\circ} \mathrm{C}$ for $1 \mathrm{~h}$

at $4{ }^{\circ} \mathrm{C}$. However, enzyme activity was less than $50 \%$ after $48 \mathrm{~h}$ at $\mathrm{pH} 5,11,12$ (Fig. 1b). The results showed that the optimal $\mathrm{pH}$ is 9.0 but the enzyme is stable at $\mathrm{pH} 7-8$.

On incubation at $\mathrm{pH} 9.0$, KerP exhibited the maximum activity at $60{ }^{\circ} \mathrm{C}$ (Fig. 2a). Enzyme activity was relatively stable below $60{ }^{\circ} \mathrm{C}$ after $60 \mathrm{~min}$ of pretreatment and declined rapidly beyond $80{ }^{\circ} \mathrm{C}$ (Fig. 2b). The optimal $\mathrm{pH}$ and temperature of the commercial keratinase KerA from $B$. licheniformis PWD-1 were $\mathrm{pH} 7.5$ and $50{ }^{\circ} \mathrm{C}$,
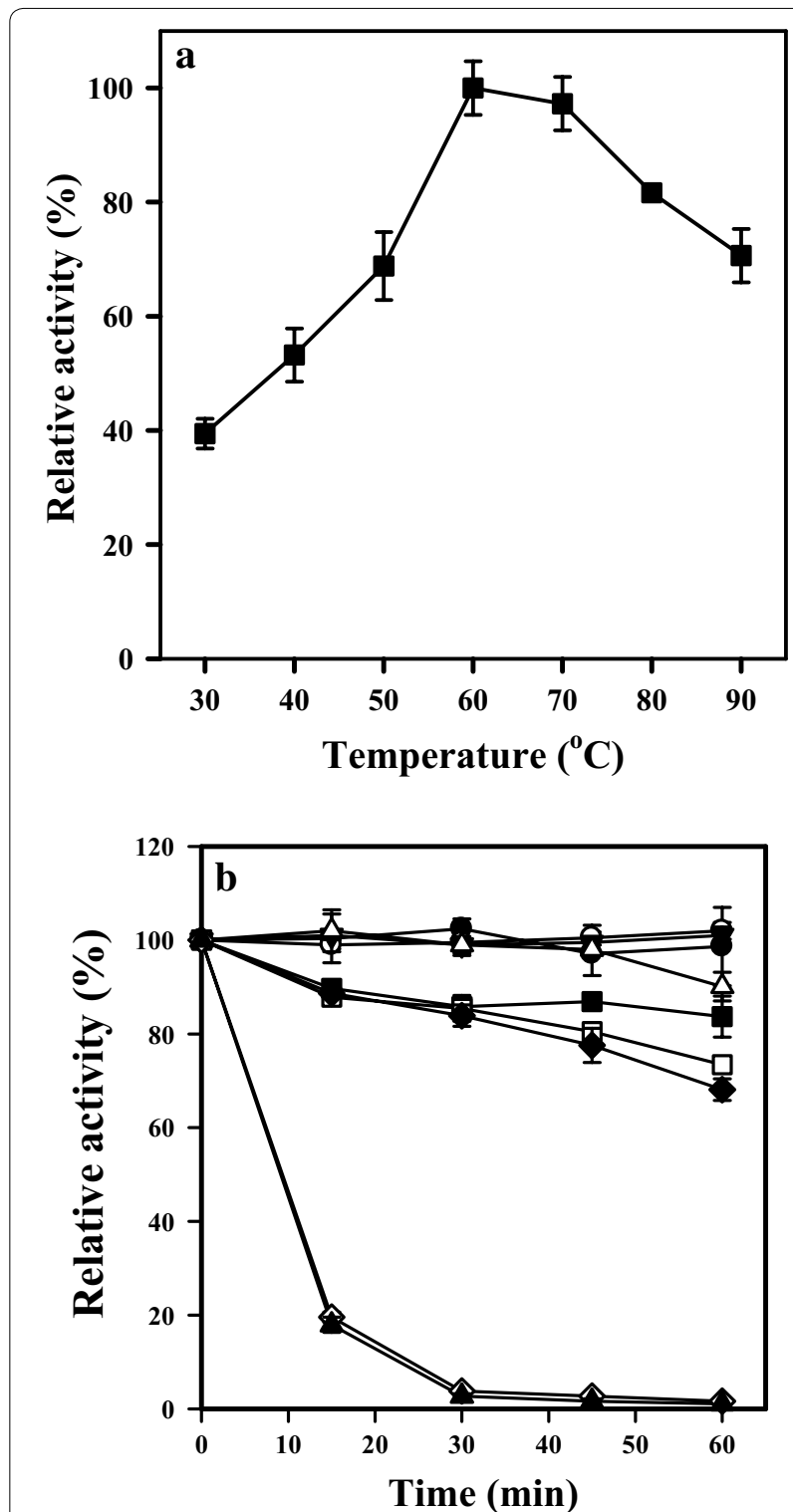

Fig. 2 a Effect of temperature on KerP activity. $\mathbf{b}$ Temperature stability of KerP. Enzyme activity was preserved at various temperatures between 0 and $60 \mathrm{~min}$ before assaying enzyme activity. $30^{\circ} \mathrm{C}$ (filled circle), $40^{\circ} \mathrm{C}$ (open circle), $50^{\circ} \mathrm{C}$ (filled inverted triangle), $60^{\circ} \mathrm{C}$ (open triangle), and $70^{\circ} \mathrm{C}$ (filled square) for $60 \mathrm{~min}$. The enzyme activity was assayed with feather powders as the substrate at $\mathrm{pH} 9.0$ for $1 \mathrm{~h}$

respectively. Keratinase KerP is similar to other bacterial keratinases in optimal conditions (Sangali and Brandelli 2000; Sookkheo et al. 2000; Zhang et al. 2016). Moreover, the stability of KerP suggested potential industrial applications.

\section{Effects of chemical compounds on KerP activity}

The effects of metal ions, inhibitors, and surfactants on KerP activity were investigated (Table 3 ). Enzyme activity 
Table 3 Effect of chemicals on KerP activity

\begin{tabular}{llr}
\hline Chemicals & Concentrations & Relative activity (\%) \\
\hline Control & - & $100 \pm 2$ \\
$\mathrm{CaCO}_{3}$ & $10 \mathrm{mM}$ & $125 \pm 2$ \\
$\mathrm{MgSO}_{4}$ & $10 \mathrm{mM}$ & $151 \pm 1$ \\
$\mathrm{MnSO}_{4}$ & $10 \mathrm{mM}$ & $158 \pm 2$ \\
$\mathrm{FeSO}_{4}$ & $10 \mathrm{mM}$ & $308 \pm 2$ \\
$\mathrm{ZnSO}_{4}$ & $10 \mathrm{mM}$ & $60 \pm 1$ \\
NiSO $_{4}$ & $10 \mathrm{mM}$ & $15 \pm 1$ \\
$\mathrm{EDTA}^{4}$ & $1 \mathrm{mM}$ & $47 \pm 1$ \\
$\mathrm{PMSF}$ & $1 \mathrm{mM}$ & $8 \pm 1$ \\
$\mathrm{SDS}$ & $1 \%$ & $279 \pm 2$ \\
$\beta_{-m e r c a p t o e t h a n o l}$ & $1 \%$ & $31 \pm 1$ \\
Triton X-100 & $1 \%$ & $109 \pm 5$ \\
Tween-80 & $1 \%$ & $100 \pm 1$ \\
\hline
\end{tabular}

was enhanced by $\mathrm{Fe}^{2+}$ and SDS but significantly inhibited by $\mathrm{Ni}^{2+}, \mathrm{Zn}^{2+}$, EDTA, PMSF, and $\beta$-mercaptoethanol. Because KerP was strongly inhibited by EDTA (relative activity $47 \%$ ) and PMSF (relative activity $8 \%$ ), it may be a serine protease or a serine-metalloproteinase (Brandelli 2008). Moreover, the detergent SDS enhanced the enzyme activity by 2.79 folds, thereby suggesting that KerP could resist the detergent and that the detergent could increase the surface contact between the feathers and the enzyme. Compared to other keratinases (Su et al. 2017a; Zhang et al. 2016), KerP has higher potential for application in commercial cleaning or bath products that contain SDS.

\section{Enhancement of the KerP secretion in B. subtilis}

Various bacterial expression systems were utilized for keratinase production, and B. subtilis was a better and more efficient host for keratinase production (Haddar et al. 2009; Lin et al. 1997; Liu et al. 2014; Zaghloul et al. 2011). All of them used the expression vectors to heterologously produce keratinase in B. subtilis. However, the expression plasmid used in B. subtilis would lead to problems of plasmid instability, which could reduce enzyme production, thereby interfering with enzyme production at the industrial level. The segregational and structural instability of $B$. subtilis plasmids are the two major, clearly described problems (Chen et al. 2007). To overcome these problems, researchers used theta mode plasmids that provide complete structural stability to express the enzyme. However, this type of plasmid still has the problem of segregational instability. The segregational instability of $B$. subtilis plasmids can be stabilized through the addition of selection marker (antibiotics or the deficiency components of amino acids) in the culture medium; however, this would increase the cost of fermentation and affect the environment in the industrial fermentation process. For industrial enzyme production, strain stability is critical for mass production of proteins of interest. Moreover, the enhancement of secretion of the recombinant protein is also a pivotal point in the $B$. subtilis expression system. For secretion, proteins need to be guided by the signal peptide. The appropriate signal peptide could enhance the secretion efficiency even though the original signal peptide may not be the best signal peptide (Chen et al. 2015). Therefore, screening of the signal peptide must be considered during the construction of the expression vector for the host.

The signal peptide sequence of KerP was compared with those in a B. subtilis database in our laboratory, and six different signal peptide candidates were amplified through PCR and replaced with the KerP original signal peptide on the vector pDMT-BpKer to increase keratinase secretion. The vectors were integrated into the $B$. subtilis PT5 chromosome to determine the keratinolytic activity of KerP. Results showed that the keratinase production was greater in three strains, PT5(DMT01mKerP), PT5(DMT06-mKerP), and PT5(DMT12mKerP), than in PT5(DMT-KerP) (Fig. 3). The highest production of $\operatorname{KerP}(473 \pm 20 \mathrm{U} / \mathrm{mL})$ was observed in PT5(DMT01-mKerP); its keratinase production was 1.55 times that of PT5(DMT-KerP), which used the original signal peptide of KerP, thereby indicating that the original signal peptide of KerP from B. polyfermenticus B4

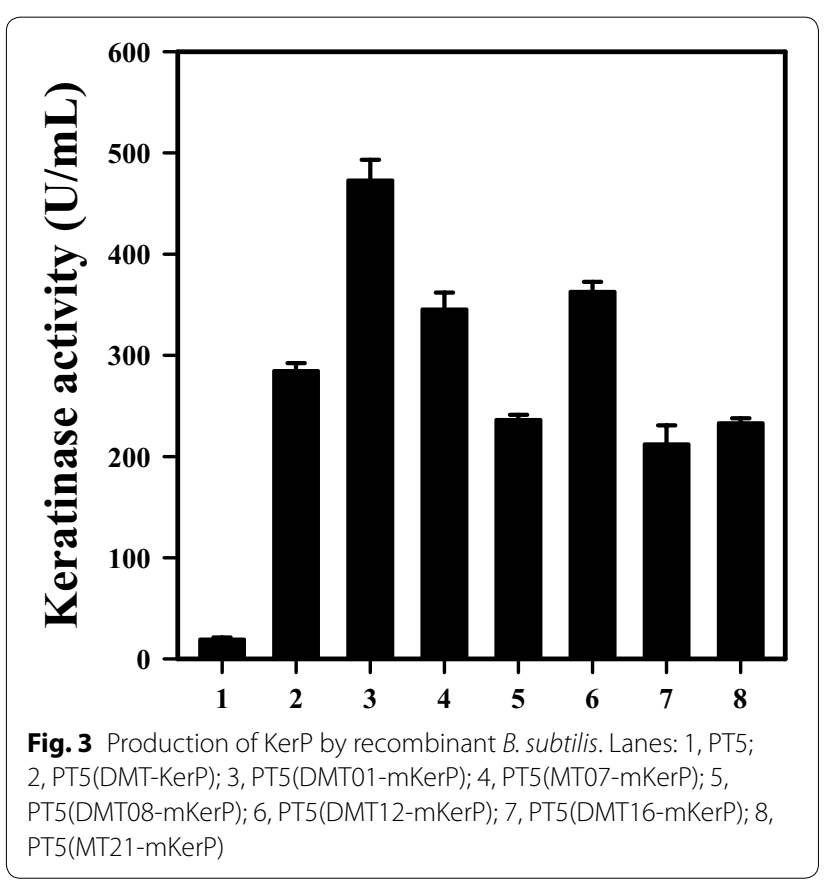


could not result in the highest production of $\operatorname{KerP}$ in $B$. subtilis.

\section{Batch fermentation of KerP-producing B. subtilis}

Batch fermentation of PT5(DMT1-mKerP) was executed in a 5-L fermenter for producing KerP. Because of the characteristics of B. subtilis (Chen et al. 2007; Su et al. 2017b), the $\mathrm{pH}$ was not regulated during fermentation. KerP production was gradually increased with an increase in fermentation time. Keratinolytic activity was $467 \pm 26 \mathrm{U} / \mathrm{L}(81.7 \pm 5.6 \mathrm{mg} / \mathrm{L})$ after $24 \mathrm{~h}$ of fermentation (Fig. 4a and b). The enzyme production through fermentation was similar to that through shake flask cultivation. Compared with that in previous studies (Chen et al. 2007, 2015; Su et al. 2017b), the yield of keratinase was the highest when using LB broth as the fermentation medium.

\section{Conclusions}

The keratinolytic strain B. polyfermenticus B4 was isolated from a poultry farm in Tainan, Taiwan, and its keratinase KerP was successfully cloned and expressed in B. subtilis PT5. Biochemical analysis revealed that the maximum keratinolytic activity of recombinant KerP was achieved at $\mathrm{pH} 9.0$ and $60{ }^{\circ} \mathrm{C}$. Enzyme activity could be enhanced with $\mathrm{Fe}^{2+}, \mathrm{Mn}^{2+}$, and SDS, and inhibited by $\mathrm{Zn}^{2+}, \mathrm{Ni}^{2+}$, EDTA, PMSF, and $\beta$-mercaptoethanol. The highest production of KerP was possible with the use of B. subtilis aprE signal peptide (Fig. 4a and b). KerP has potential applications in industry and in the treatment of

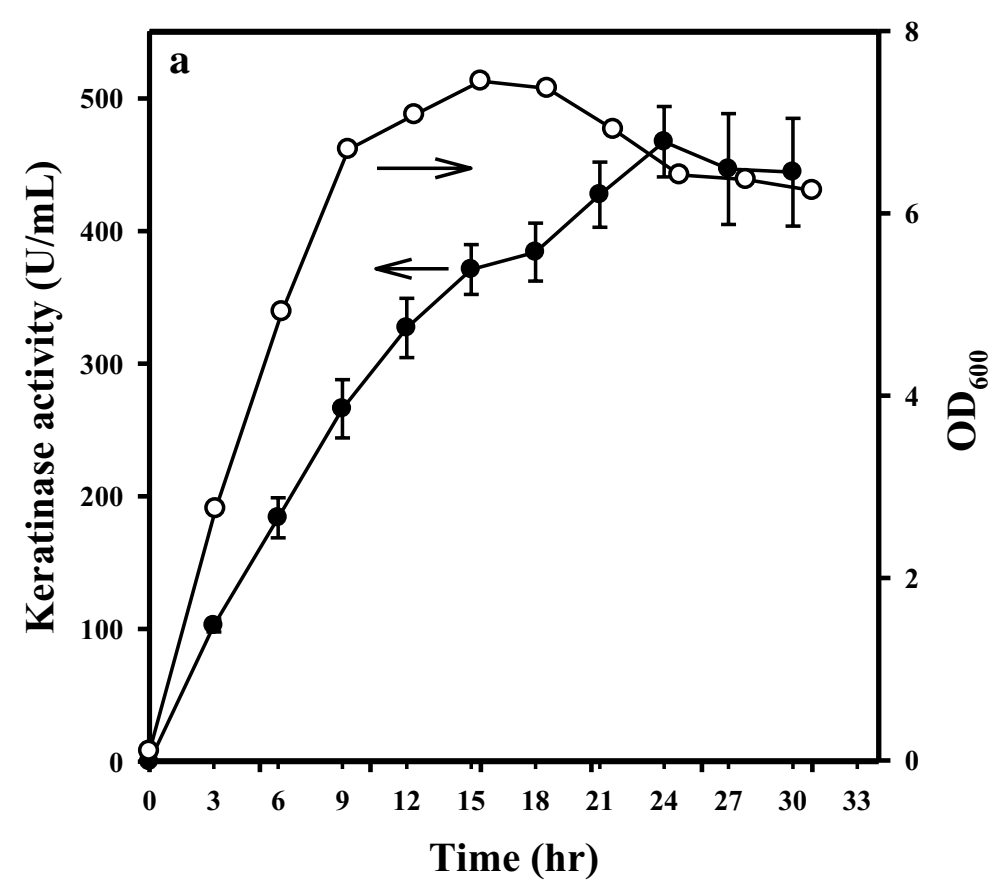

b

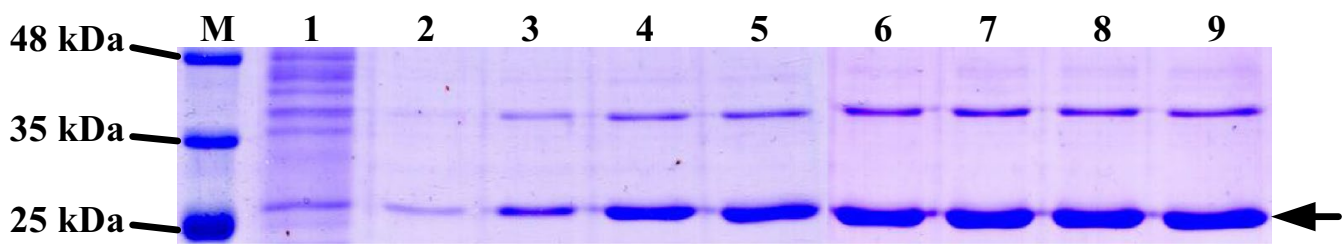

Fig. 4 a Batch fermentation of recombinant KerP-producing strain PT5(DMT01-mKerP) in a 5-L fermenter. Cell density was determined during fermentation (closed circles) at $\mathrm{OD}_{600}$, and the production of KerP was assayed through measurement of keratinolytic activity (open circles). $\mathbf{b}$ SDS-PAGE analysis of KerP secreted by recombinant B. subtilis PT5(DMT01-mKerP). Fifteen microliters of culture broth from different fermentation periods was drawn out for PAGE. Lanes M, protein marker; lane 1, the culture broth of PT5 after 24-h fermentation; the culture broth of strain PT5(DMT01-mKerP) after fermentation for lane 2, 3 h; lane 3, 6 h; lane 4, 9 h; lane 5, 12 h; lane 6, 15 h; lane 7, 18 h; lane 8, 21 h; and lane 9, 24 h. The arrow indicates the position of KerP 
keratinolytic waste. Future studies are required to standardize media composition and investigate scale-up fermentation strategies.

\section{Additional file}

Additional file 1: Figure S1. BLAST results of KerP and Bacillus polyfermenticus alkaline protease precursor (ADP23919.1). The data revealed 99\% homology between KerP and ApBp. The amino acid residues at positions $1,26,68$, and 103 are different (red words).

\section{Abbreviations}

erm: selection marker of erythromycin resistant; kerp: keratinase KerP fulllength gene; mkerP: keratinase KerP mature sequence; $\mathrm{P}_{\mathrm{T} 7}: \mathrm{T7}$ promoter; $\mathrm{SP}$ : signal peptide.

\section{Authors' contributions}

PT designed the experiments, analyzed the data, and wrote the manuscript. YZ conducted most of the experiments, and WS provided the experimental materials and performed a few experiments. All authors read and approved the final manuscript.

\section{Author details}

${ }^{1}$ Department of Biotechnology, Southern Taiwan University of Science and Technology, Tainan 710, Taiwan. ${ }^{2}$ Net-Bio Biotechnology Enterprise Co., LTD, Tainan 710, Taiwan.

\section{Acknowledgements}

Not applicable.

\section{Competing interests}

The authors declare that they have no competing interests.

\section{Availability of data and materials}

All data generated or analyzed during this study are included in the main manuscript file.

\section{Consent for publication}

The authors approved the consent for publishing the manuscript.

\section{Ethics approval and consent to participate}

All authors have read and agreed the ethics for publishing the manuscript.

\section{Funding}

Funding information is not applicable.

\section{Publisher's Note}

Springer Nature remains neutral with regard to jurisdictional claims in published maps and institutional affiliations.

Received: 25 September 2017 Accepted: 11 November 2017

Published online: 16 November 2017

\section{References}

Bhange K, Chaturvedi V, Bhatt R (2016) Ameliorating effects of chicken feathers in plant growth promotion activity by a keratinolytic strain of Bacillus subtilis PF1. Bioresour Bioprocess 3(1):13

Brandelli A (2008) Bacterial keratinases: useful enzymes for bioprocessing agroindustrial wastes and beyond. Food Bioprocess Technol 1(2):105-116

Brandelli A, Daroit DJ, Riffel A (2010) Biochemical features of microbial keratinases and their production and applications. Appl Microbiol Biotechnol 85(6):1735-1750
Bressollier P, Letourneau F, Urdaci M, Verneuil B (1999) Purification and characterization of a keratinolytic serine proteinase from Streptomyces albidoflavus. Appl Environ Microbiol 65(6):2570-2576

Brockmeier U, Caspers M, Freudl R, Jockwer A, Noll T, Eggert T (2006) Systematic screening of all signal peptides from Bacillus subtilis: a powerful strategy in optimizing heterologous protein secretion in Gram-positive bacteria. J Mol Biol 362(3):393-402

Chao YP, Chiang CJ, Hung WB (2002) Stringent regulation and high-level expression of heterologous genes in Escherichia coli using T7 system controllable by the araBAD promoter. Biotechnol Prog 18(2):394-400

Chen PT, Chiang CJ, Chao YP (2007) Strategy to approach stable production of recombinant nattokinase in Bacillus subtilis. Biotechnol Prog 23(4):808-813

Chen PT, Shaw J-F, Chao Y-P, David Ho T-H, Yu S-M (2010) Construction of chromosomally located $\mathrm{T7}$ expression system for production of heterologous secreted proteins in Bacillus subtilis. J Agric Food Chem 58(9):5392-5399

Chen PT, Chen Y-C, Lin Y-Y, Su H-H (2015) Strategy for efficient production of recombinant Staphylococcus epidermidis lipase in Bacillus subtilis. Biochem Eng J 103:152-157

Coulombe PA, Omary MB (2002) 'Hard' and 'soft' principles defining the structure, function and regulation of keratin intermediate filaments. Curr Opin Cell Biol 14(1):110-122

de Boer Sietske A, Diderichsen B (1991) On the safety of Bacillus subtilis and B. amyloliquefaciens: a review. Appl Microbiol Biotechnol 36(1):1-4

Fakhfakh-Zouari N, Haddar A, Hmidet N, Frikha F, Nasri M (2010) Application of statistical experimental design for optimization of keratinases production by Bacillus pumilus A1 grown on chicken feather and some biochemical properties. Process Biochem 45(5):617-626

Gupta R, Ramnani P (2006) Microbial keratinases and their prospective applications: an overview. Appl Microbiol Biotechnol 70(1):21

Gupta R, Rajput R, Sharma R, Gupta N (2013) Biotechnological applications and prospective market of microbial keratinases. Appl Microbiol Biotechnol 97(23):9931-9940

Haddar HO, Zaghloul TI, Saeed HM (2009) Biodegradation of native feather keratin by Bacillus subtilis recombinant strains. Biodegradation 20(5):687

Harwood CR (1992) Bacillus subtilis and its relatives: molecular biological and industrial workhorses. Trends Biotechnol 10:247-256

Khardenavis AA, Kapley A, Purohit HJ (2009) Processing of poultry feathers by alkaline keratin hydrolyzing enzyme from Serratia sp. HPC 1383. Waste Manag 29(4):1409-1415

Kim S-J, Chun J, Bae KS, Kim Y-C (2000) Polyphasic assignment of an aromaticdegrading Pseudomonas sp., strain DJ77, in the genus Sphingomonas as Sphingomonas chungbukensis sp. nov. Int J Syst Evol Microbiol 50(4):1641-1647

Korniłłowicz-Kowalska T, Bohacz J (2011) Biodegradation of keratin waste: theory and practical aspects. Waste Manag 31(8):1689-1701

Kreplak L, Doucet J, Dumas P, Briki F (2004) New aspects of the a-helix to $\beta$-sheet transition in stretched hard a-keratin fibers. Biophys $\mathrm{J}$ 87(1):640-647

Li W, Zhou X, Lu P (2004) Bottlenecks in the expression and secretion of heterologous proteins in Bacillus subtilis. Res Microbiol 155(8):605-610

Lin X, Kelemen DW, Miller ES, Shih J (1995) Nucleotide sequence and expression of kerA, the gene encoding a keratinolytic protease of Bacillus licheniformis PWD-1. Appl Environ Microbiol 61(4):1469-1474

Lin X, Wong S, Miller E, Shih J (1997) Expression of the Bacillus licheniformis PWD-1 keratinase gene in B. subtilis. J Ind Microbiol Biotechnol 19(2):134-138

Liu B, Zhang J, Gu L, Du G, Chen J, Liao X (2014) Comparative analysis of bacterial expression systems for keratinase production. Appl Biochem Biotechnol 173(5):1222-1235

Olajuyigbe FM, Falade AM (2014) Purification and partial characterization of serine alkaline metalloprotease from Bacillus brevis MWB-01. Bioresour Bioprocess 1(1):8

Onifade A, Al-Sane N, Al-Musallam A, Al-Zarban S (1998) A review: potentials for biotechnological applications of keratin-degrading microorganisms and their enzymes for nutritional improvement of feathers and other keratins as livestock feed resources. Bioresour Technol 66(1):1-11

Pohl S, Harwood CR (2010) Heterologous protein secretion by Bacillus species: from the cradle to the grave. Adv Appl Microbiol 73:1-25

Radha S, Gunasekaran P (2008) Sustained expression of keratinase gene under PxyIA and PamyL promoters in the recombinant Bacillus megaterium MS941. Bioresour Technol 99(13):5528-5537 
Sangali S, Brandelli A (2000) Isolation and characterization of a novel featherdegrading bacterial strain. Appl Biochem Biotechnol 87(1):17-24

Schallmey M, Singh A, Ward OP (2004) Developments in the use of Bacillus species for industrial production. Can J Microbiol 50(1):1-17

Schrooyen PM, Dijkstra PJ, Oberthür RC, Bantjes A, Feijen J (2001) Partially carboxymethylated feather keratins. 2. Thermal and mechanical properties of films. J Agric Food Chem 49(1):221-230

Sookkheo B, Sinchaikul S, Phutrakul S, Chen S-T (2000) Purification and characterization of the highly thermostable proteases from Bacillus stearothermophilus TLS33. Protein Expr Purif 20(2):142-151

Su C, Gong J-S, Zhang R-X, Tao L-Y, Dou W-F, Zhang D-D, Li H, Lu Z-M, Xu Z-H, Shi J-S (2017a) A novel alkaline surfactant-stable keratinase with superior feather-degrading potential based on library screening strategy. Int J Biol Macromol 95:404-411

Su P-C, Hsueh W-C, Chang W-S, Chen PT (2017b) Enhancement of chitosanase secretion by Bacillus subtilis for production of chitosan oligosaccharides. J Taiwan Inst Chem Eng 79:49-54

Tjalsma H, Antelmann H, Jongbloed JD, Braun PG, Darmon E, Dorenbos R, Dubois J-YF, Westers H, Zanen G, Quax WJ (2004) Proteomics of protein secretion by Bacillus subtilis: separating the "secrets" of the secretome. Microbiol Mol Biol Rev 68(2):207-233
Vermelho AB, Mazotto AM, de Melo ACN, Vieira FHC, Duarte TR, Macrae A, Nishikawa MM, da Silva Bon EP (2010) Identification of a Candida parapsilosis strain producing extracellular serine peptidase with keratinolytic activity. Mycopathologia 169(1):57

Wang X, Parsons C (1997) Effect of processing systems on protein quality of feather meals and hog hair meals. Poult Sci 76(3):491-496

Westers L, Westers H, Quax WJ (2004) Bacillus subtilis as cell factory for pharmaceutical proteins: a biotechnological approach to optimize the host organism. Biochim Biophys Acta 1694(1):299-310

Zaghloul TI, Embaby AM, Elmahdy AR (2011) Key determinants affecting sheep wool biodegradation directed by a keratinase-producing Bacillus subtilis recombinant strain. Biodegradation 22(1):111-128

Zhang R-X, Gong J-S, Su C, Zhang D-D, Tian H, Dou W-F, Li H, Shi J-S, Xu Z-H (2016) Biochemical characterization of a novel surfactant-stable serine keratinase with no collagenase activity from Brevibacillus parabrevis CGMCC 10798. Int J Biol Macromol 93:843-85

\section{Submit your manuscript to a SpringerOpen ${ }^{\circ}$ journal and benefit from:}

- Convenient online submission

- Rigorous peer review

- Open access: articles freely available online

- High visibility within the field

- Retaining the copyright to your article

Submit your next manuscript at $\boldsymbol{\nabla}$ springeropen.com 